\title{
Praktik Dokter Dalam Pemberian Pelayanan Kesehatan Pada Pasien HIV dan AIDS di Rumah Sakit Rujukan di Kota Semarang
}

\author{
Miralda Septri Dewi*), Zahroh Shaluhiyah ${ }^{* *}$, Antono Suryoputro**) \\ *) Alumni Magister Promosi Kesehatan Universitas Diponegoro Semarang \\ **) Magister Promosi Kesehatan Universitas Diponegoro Semarang
}

\begin{abstract}
ABSTRAK
Kota Semarang merupakan kota dengan angka kasus HIV dan AIDS tertinggi di Jawa Tengah. Dalam upaya penyelenggaraan pelayanan kesehatan bagi orang dengan HIV dan AIDS (ODHA), terdapat tiga rumah sakit yang aktif memberikan layanan Perawatan, Dukungan dan Pengobatan (PDP) yang ditunjuk sebagai rumah sakit rujukan bagi ODHA di Kota Semarang. Salah satu hambatan dalam upaya penanggulangan HIV dan AIDS yang membuat ODHA enggan untuk berobat atau mengakses layanan kesehatan dan dukungan sosial yang semestinya dapat mereka peroleh adalah mereka takut akan mendapatkan stigma dan diskriminasi di fasilitas pelayanan kesehatan. Menurut beberapa hasil penelitian yang pernah ada menunjukkan bahwa masih ada stigma dan diskriminasi yang dilakukan oleh petugas kesehatan termasuk dokter. Penelitian ini bertujuan mengetahui praktik dokter dalam pemberian pelayanan kesehatan pada pasien HIV dan AIDS di Rumah Sakit Rujukan di Kota Semarang. Penelitian ini menggunakan metode kualitatif. Pengumpulan data menggunakan wawancara mendalam pada 13 dokter sebagai informan primer dan triangulasi kepada ketua tim HIV. Hasil penelitian menunjukkan bahwa praktik sebagian besar dokter baik, yaitu tidak melakukan pembedaan perlakuan atau tidak mendiskriminasi saat memberikan pelayanan kesehatan kepada pasien HIV dan AIDS. Namun, masih ada sebagian kecil dokter yang berpraktik kurang baik yaitu diskriminatif ketika memberikan pelayanan kesehatan kepada pasien HIV dan AIDS yaitu dengan penggunaan APD yang dilebihkan daripada saat menangani pasien bukan ODHA, seperti penggunaan sarung tangan double. Sebagian besar dokter memiliki pengetahuan yang baik dan sikap positif terhadap pasien HIV dan AIDS. Namun, masih ada sebagian kecil dokter yang memiliki pemahaman HIV dan AIDS yang kurang baik.
\end{abstract}

Kata kunci : Praktik dokter, pasien HIV dan AIDS, rumah sakit

\begin{abstract}
Doctors Practice in Providing Health Care for HIV And AIDS Patients In Semarang Referral Hospital

Semarang City had a highest cases of HIV and AIDS in Central Java. In order to provide health care service for People with HIV and AIDS (PLWHA), three from the five designated hospitals were actively providing Care, Support and Treatment (CST) as a referral hospital for PLWHA in Semarang City. HIV-related discrimination is one of the barrier in the response to HIV and AIDS that influenced PLWHA to seek HIV treatment and lost of HIV treatment because they were afraid of getting stigma and discrimination in health care facilities. Some research have indicated that there were stigma and discrimination by health workers, including doctors. This study aims to find out doctors practices in providing health care to patients with HIV and AIDS in a referral hospital in Semarang City. This study used qualitative methods. The data collecting used indepth interview. The data was collected from
\end{abstract}


13 doctors as a primary informants and triangulation with 3 HIV team leader. The results showed that the majority of doctors practice was good, they did not discriminate when providing care or treatment to patients with HIV and AIDS. However, there were still a some doctors who discriminate when providing care for patients with HIV and AIDS such as the use of Personal Protective Equipment (PPE) was more strictly when dealing with patients of PLWHA like using double gloves. Most doctors have a good knowledge and positive attitudes towards HIV and AIDS. However, there were some doctors who has less understanding of HIV and AIDS.

Keywords : doctor practice, HIV and AIDS patients, hospitals

\section{PENDAHULUAN}

Berdasarkan laporan perkembangan HIV dan AIDS di Indonesia triwulan II tahun 2013, Jawa Tengah merupakan Provinsi nomor 7 dengan jumlah kumulatif kasus HIV tertinggi yaitu 5.406 kasus, dan merupakan Provinsi nomor 6 dengan jumlah kumulatif kasus AIDS terbanyak yaitu 2.990 kasus (Kemenkes RI, 2013). Kota Semarang merupakan kota dengan angka kasus HIV dan AIDS tertinggi di Jawa Tengah (Kemenkes RI, 2013). Berdasarkan data kasus kumulatif HIV tahun 1995 sampai dengan Agustus 2013, jumlah kasus HIV mencapai 2.555 orang dan jumlah kasus kumulatif AIDS tahun 1998 sampai dengan Agustus 2013 mencapai 387 orang (DKK Semarang, 2014). Sedangkan pada tahun 2013 di Kota Semarang telah terjadi 430 kasus HIV baru, angka AIDS mencapai 75 dengan jumlah kematian 7 jiwa (DKK Semarang, 2014).

Kebutuhan pelayanan kesehatan bagi Orang dengan HIV dan AIDS (ODHA)

semakin meningkat seiring dengan bertambah besarnya jumlah orang yang terinfeksi HIV. Namun, beberapa hasil penelitian sebelumnya di beberapa tempat menunjukkan bahwa masih ada penyedia atau pemberi pelayanan kesehatan yang bertindak diskriminatif pada ODHA. Seperti hasil penelitian di Kota Bandung yang menunjukkan bahwa di institusi kesehatan pun masih banyak terjadi tindakan diskriminatif walaupun kebanyakan tenaga kesehatan telah memiliki pengetahuan yang cukup memadai mengenai HIV dan AIDS. Tindakan diskriminatif ini antara lain adalah tes diagnostik HIV tanpa informed consent kepada pasien yang akan dilakukan tindakan operatif, tenaga kesehatan tidak mau 
melakukan kontak fisik seperti jabat tangan dan pemeriksaan fisik dasar dengan ODHA (Nurhayati, 2013). Penelitian di Banda Aceh juga menunjukkan bahwa diskriminasi tenaga kesehatan terhadap ODHA masih tinggi, dimana pengetahuan tentang penularan dan pencegahan HIV merupakan faktor prediktor munculnya diskriminasi pada tenaga kesehatan terhadap ODHA (Harapan, 2013).

Hasil survei terhadap ODHA pada tahun 2004 di 20 provinsi, termasuk Jawa Tengah didalamnya, juga menunjukkan bahwa hampir 30\% ODHA pernah mengalami diskriminasi di bidang layanan kesehatan (oleh rumah sakit atau petugas kesehatan) karena status HIV-nya. Bentuk diskriminasi yang sering dialami yaitu petugas kesehatan menolak menangani karena status HIV-nya positif, dan diperlambat dalam pengobatan atau layanan kesehatan (Yayasan Spiritia, 2005). Berdasarkan penelitian Yayasan Spiritia tahun 2011 di 10 Provinsi, menunjukkan bahwa kurang dari 15\% ODHA yang menjadi responden penelitian mengalami stigma (berkisar antara 3,3$12,5 \%)$. Dari mereka yang mengalami stigma tersebut, paling banyak mendapatkan stigma dari dokter yaitu $13 \%$. Selain itu, ditemukan bahwa ODHA yang mendapatkan diskriminasi dari dokter sebanyak 7\% (Mardiati, 2011).

Menurut hasil penelitian partisipatif ODHA oleh KPA terkait dengan akses pelayanan kesehatan dasar, hampir semua ODHA yang menjadi partisipan penelitian dan yang pernah mengakses layanan baik untuk tes, konseling, terapi, maupun perawatan pernah merasakan diskriminasi dari petugas kesehatan di berbagai tempat layanan kesehatan. Contohnya adalah pelanggaran terhadap universal precautions (UP) dan pelanggaran terhadap Standart Operational Procedure (SOP). Dalam FGD di Sukabumi, seorang partisipan menyatakan sikap dokter dalam menangani ODHA dijadikan second prioritas yaitu ODHA ditangani sebagai pasien terakhir meskipun datang pertama, selain itu kerahasiaan belum terjaga oleh petugas laboratorium saat test HIV (KPAN, 2006).

Menurut hasil penelitian yang dilakukan oleh Merati dan kawan-kawan, bentuk diskriminasi terhadap ODHA dalam pelayanan kesehatan berupa penolakan pemberian layanan kesehatan pada ODHA, perlakuan yang berbeda pada ODHA, mengekspos status HIV pasien pada pihak lain, dan mengisolasikan pasien ODHA. Keterbatasan fasilitas untuk pelayanan 
kesehatan HIV dan AIDS seringkali dijadikan strategi untuk menutupi diskriminasi petugas kesehatan terhadap ODHA. Dengan alasan tersebut, petugas kesehatan seringkali menyarankan ODHA untuk mencari tempat layanan kesehatan lain supaya mereka terhindar dari tugasnya. Hal ini merupakan bentuk respon petugas kesehatan terhadap ketidaksiapannya menghadapi pasien HIV dan AIDS (Merati, 2005). Tindakan diskriminatif yang terjadi di pelayanan kesehatan merupakan masalah yang dihadapi dalam pemberian layanan kesehatan. Keterbatasan informasi dan pengetahuan tentang HIV dan AIDS menyebabkan rasa takut tertular virus HIV yang berlebihan pada petugas kesehatan dan seringkali menyebabkan diskriminasi dan tidak rasional terhadap ODHA (Robinson, 1998).

Akses ke perawatan sangat penting untuk menjaga kesehatan, kesejahteraan, dan kualitas hidup ODHA (Kinsler, 2007). Sedangkan sikap menstigma dan diskriminasi terhadap ODHA yang tergambar dalam sikap sinis, perasaan ketakutan yang berlebihan dan persepsi negatif tentang ODHA, dapat mempengaruhi dan menurunkan kualitas hidup ODHA. Karena ketakutan terhadap stigma dan diskriminasi mengakibatkan mereka yang hidup dengan HIV terlambat atau tidak mau mengakses layanan Perawatan, Dukungan, dan Pengobatan (PDP) yang mereka butuhkan karena takut membuka status mereka kepada yang lain (Kemenkes RI, 2012). Oleh karena itu, tenaga kesehatan sebagai pemberi layanan kesehatan perlu untuk lebih siap menghadapi pasien ODHA. Karena setiap orang berhak mendapatkan perawatan dan pengobatan yang sebaik-baiknya tanpa dibedakan (Murni, 2003).

Pencegahan HIV merupakan prioritas global dan sikap petugas kesehatan merupakan dimensi kunci untuk kesuksesan upaya pencegahan HIV (Webber, 2007). Sikap menstigma dan diskriminasi yang dilakukan oleh pekerja sektor kesehatan terhadap pasien HIV dan AIDS merupakan masalah dalam lingkungan pelayanan kesehatan yang akan menurunkan penyediaan perawatan dan program-program pencegahan. Bentuknya berbagai macam dan dapat menyebabkan pengobatan yang terlambat, tidak tepat atau terganggu, merusak kerahasiaan, perilaku yang tidak pantas atau tidak etis, dan penggunaan kewaspadaan yang berlebihan (ILO, 2005). Hal ini merupakan kendala dalam mewujudkan akses kesehatan universal bagi 
ODHA, dan kendala kualitas pemberian pelayanan kesehatan kepada ODHA sehingga dapat menjadi penghalang bagi ODHA untuk menjangkau ketersediaan pelayanan kesehatan yang pada akhirnya dapat menurunkan derajat kesehatan ODHA (Paryati, 2013).

Dalam upaya penyelenggaraan pelayanan kesehatan bagi orang dengan HIV dan AIDS (ODHA), pemerintah telah menyediakan layanan kesehatan dengan menunjuk beberapa rumah sakit menjadi rumah sakit rujukan bagi ODHA. Berdasarkan Kepmen Kesehatan RI No 451/Menkes/SK/XII/2012, ada lima rumah sakit yang ditunjuk sebagai rumah sakit rujukan bagi orang dengan HIV dan AIDS di Kota Semarang (Kemenkes RI, 2012). Namun, berdasarkan laporan Kemenkes 2013, Rumah Sakit yang aktif memberikan layanan Perawatan, Dukungan dan Pengobatan (PDP) di Kota Semarang hanya tiga dari lima rumah sakit yang ditunjuk sebagai rumah sakit rujukan bagi orang dengan HIV dan AIDS (Kemenkes RI, 2013).

Salah satu hambatan dalam upaya penanggulangan HIV dan AIDS yang membuat ODHA enggan untuk berobat atau mengakses layanan kesehatan yang diperlukan dan dukungan sosial yang semestinya dapat mereka peroleh adalah karena mereka takut akan mendapatkan stigma dan diskriminasi di fasilitas pelayanan kesehatan (Rostini, 2010). Rumah sakit merupakan instansi kesehatan yang berperan penting melawan penyebaran HIV dan AIDS (Purwaningtyas, 2007). ODHA yang enggan datang lagi ke pelayanan kesehatan kerena merasakan ketidaknyamanan dalam pelayanan dapat mempengaruhi ODHA dalam melakukan ART sehingga dapat menyebabkan drop out pengobatan. Hal ini menjadi penting karena sekali saja mereka putus obat, maka virus akan kebal atau terjadi resistensi terhadap ARV sehingga harus diganti dengan rejimen yang lebih sensitif. Seseorang yang menderita HIV dan tidak mendapatkan ART dapat memasuki fase AIDS dan mengalami berbagai infeksi oportunistik. Selain itu, keengganan seseorang untuk melakukan test HIV di layanan kesehatan dapat menyebarkan penularan HIV kepada orang lain karena tidak mengetahui status HIV pada dirinya. Sehingga hal ini dapat berpengaruh terhadap peningkatan angka HIV dan AIDS.

Penderita HIV dan AIDS sangat rentan terhadap infeksi dan memilki risiko terkena penyakit lebih besar sehingga seumur hidupnya bergantung pada dukungan medis. 
Program pengendalian HIV sejak beberapa tahun belakangan ini telah mengalami banyak kemajuan dan berbagai layanan terkait HIV telah dikembangkan dan dimanfaatkan oleh masyarakat yang membutuhkannya. Namun, teridentifikasi bahwa perkembangan dari efektifitas maupun kualitas intervensi dan layanannya masih belum maksimal. Situasi ini dapat dilihat dari rendahnya cakupan, adanya kesenjangan koordinasi antara layanan dengan pelaksana program yang lain. Akibatnya, upaya penanggulangan HIV maupun peningkatan kualitas hidup ODHA mengalami hambatan (Kemenkes RI, 2012). Dokter merupakan tenaga kesehatan yang berperan secara langsung maupun tidak langsung dalam penanganan pasien HIV dan AIDS. Sedangkan menurut penelitian Yayasan Spiritia tahun 2011 menunjukkan bahwa ODHA yang menjadi responden penelitian paling banyak mendapatkan stigma dari dokter dan ditemukan juga ODHA masih mendapatkan diskriminasi dari dokter (Mardiati, 2011). Selain itu, menurut hasil penelitian Mahendra, et al menunjukkan bahwa stigma lebih banyak dimiliki oleh dokter dibandingkan dengan perawat dan staf bangsal di rumah sakit (Mahendra, 2007). Begitu juga dengan hasil penelitian Andrewin yang menunjukkan bahwa dokter menunjukkan stigmatisasi lebih besar daripada perawat (Andrewin, 2008). Padahal ketakutan terhadap stigma dan diskriminasi mengakibatkan mereka yang hidup dengan HIV terlambat atau tidak mau mengakses layanan Perawatan, Dukungan, dan Pengobatan (PDP) yang mereka butuhkan karena takut membuka status mereka kepada yang lain (Kemenkes RI, 2012). Dari uraian tersebut peneliti melakukan penelitian tentang praktik dokter dalam pemberian pelayanan kesehatan pada pasien HIV dan AIDS di rumah sakit rujukan di Kota Semarang.

\section{METODE}

Jenis penelitian ini adalah penelitian kualitatif. Penelitian dilaksanakan tahun 2014 pada 13 dokter di poliklinik rawat jalan di tiga rumah sakit rujukan HIV dan AIDS di Kota Semarang dan triangulasi kepada ketua tim HIV di masing-masing rumah sakit tersebut. Prosedur sampling dilakukan dengan cara purposive sampling. Variabel dalam penelitian ini adalah pengetahuan, persepsi tingkat resiko penularan HIV, sikap, nilai terhadap ODHA (Stigma), dukungan institusi, dan sikap/perilaku rekan kerja terhadap pasien ODHA untuk melihat 
pengaruhnya terhadap praktik dokter dalam pemberian pelayanan kesehatan pada pasien HIV dan AIDS. Pengumpulan data dilakukan dengan cara wawancara secara mendalam (indepth interview) dengan menggunakan panduan wawancara. Hasil penelitian dianalisis secara induktif, dan hasil penelitian kualitatif lebih menekankan makna daripada generalisasi.

\section{HASIL DAN PEMBAHASAN}

Praktik Dokter dalam Pemberian Pelayanan Kesehatan Pasien HIV dan AIDS

Berdasarkan hasil penelitian, praktik sebagian besar dokter sudah baik, yaitu tidak melakukan pembedaan perlakuan atau tidak mendiskriminasi saat memberikan pelayanan kesehatan kepada pasien HIV dan AIDS seperti tidak ada penolakan pelayanan, tidak ada perbedaan dalam penerapan kewaspadaan standar, tidak memberikan tanda khusus atau label di depan catatan medis, tidak ada pemisahan ruangan, dan tidak ada penundaan pelayanan.
Namun, masih ada sebagian kecil dokter yang memliki praktik yang kurang baik, seperti memberikan perlakuan yang berbeda atau diskriminatif ketika memberikan pelayanan kesehatan kepada pasien HIV dan AIDS, yaitu dengan penggunaan APD yang berlebihan seperti penggunaan sarung tangan double dan penggunaan APD lengkap hanya saat tindakan pada pasien ODHA, masih ada penanganan pasien ODHA yang dilakukan setelah pasien lain di poli sudah habis, dan masih ada yang tidak mau menangani persalinan dengan alasan takut terhadap image pasien lain jika diketahui menangani pasien ODHA.

Ada informan yang mengatakan pada praktiknya penanganan pasien ODHA akan dilakukan ketika pasien lainnya sudah habis, sehingga pasien ODHA akan menunggu dibangsal hingga mendapat panggilan. Hal ini sejalan dengan penelitian partisipatif mengenai akses pelayanan kesehatan dasar oleh KPA yang menunjukkan bahwa masih ada diskriminasi bahwa sikap dokter dalam menangani ODHA dijadikan second prioritas yaitu ODHA ditangani sebagai pasien terakhir meskipun datang pertama (KPAN, 2006). Selain itu, masih ada yang menghindari bersentuhan ketika menangani pasien ODHA. Hal ini sejalan dengan 
pendapat Deacon dan hasil penelitian Nurhayati di Kota Bandung yang menunjukkan bahwa di institusi kesehatan pun masih terjadi tindakan diskriminatif diantaranya yaitu tenaga kesehatan tidak mau melakukan kontak fisik dengan ODHA (Nurhayati, 2013).

Ada yang menangani pasien ODHA dengan menekankan untuk lebih berhati-hati. Pada praktiknya sebagian kecil informan membutuhkan persiapan alat-alat terkait dengan kewaspadaan standar sebelum melakukan tindakan pada pasien ODHA sehingga penanganan pasien harus dijadwalkan terlebih dahulu. Dan sebagian kecil dari informan mengatakan bahwa penanganan untuk pasien ODHA ada alat-alat dan sterilisasi khusus. Hal ini sesuai dengan jawaban informan triangulasi yang mengatakan bahwa peralatan yang digunakan oleh pasien ODHA biasanya disendirikan dengan alasan diperlukan sterilisasi tersendiri yaitu harus direndam dengan larutan klorin 0,5\% selama 10 menit sebelum masuk ke strerilisasi secara umum. Sterilisasi yang khusus juga berlaku untuk peralatan di kedokteran gigi, dan pasien HIV yang akan melakukan tindakan gigi harus menyertakan hasil laboratorium yang menyatakan bahwa pasien tersebut benar positif HIV, jika pasien tersebut melakukan test HIV di luar rumah sakit itu maka harus membawa bukti hasil laboratorium atau melakukan test HIV lagi di rumah sakit tersebut, hal ini untuk keperluan tindakan pasca pajanan jika terjadi kecelakaan kerja. Sedangkan salah satu informan triangulasi rumah sakit mengatakan bahwa di poli gigi alat-alat untuk cabut gigi untuk pasien HIV sudah disediakan khusus. Petugas kesehatan kadang takut menangani pasien dengan HIV dan sikapnya terlalu berhati-hati terhadap pasien tersebut, sementara pada pasien yang lain biasa saja.

Berdasarkan hasil penelitian menunjukkan bahwa mereka hanya merasa takut, meskipun merasa satu handscoon juga tidak tembus, namun mereka tidak mau merisikokan diri mereka sendiri sehingga menggunakan double handscoon. Dan juga adanya anggapan bahwa penyakit HIV adalah penyakit yang mematikan. Selain itu sebagian kecil dari mereka beranggapan bahwa mereka sebagai tenaga medis memiliki tingkat resiko tertular yang cukup besar. Berdasarkan hasil triangulasi pada salah satu rumah sakit didapatkan bahwa terkadang dokter pun masih perlu diingatkan dalam penerapan kewaspadaan standar. Sedangkan informan triangulasi di dua rumah sakit lainnya mengatakan penerapan 
kewaspadan standar akan lebih ekstra atau proteksi yang dilakukan oleh tenaga medis akan lebih hati-hati ketika menangani pasien HIV dan AIDS. Seharusnya semua petugas harus selalu menerapkan kewaspadaan universal tanpa memandang status pasien. Praktik ini diskriminatif dan tidak tepat karena siapa saja dapat tertular dan menularkan karena ODHA tidak memiliki ciri-ciri yang khas. Ada kemungkinan bahwa pasien itu sendiri belum menyadari jika dirinya HIV-positif, atau walaupun hasil tesnya negatif, ia sedang dalam masa jendela (Murni, 2003). Diskriminasi yang bertujuan untuk mencegah infeksi kadang-kadang tidak didasarkan pada risiko infeksi HIV yang sebenarnya tetapi pada pengetahuan ilmiah yang salah atau anggapan risiko potensial yang terlalu tinggi (overestimation potential risk) (Deacon, 2005).

Dari tiga rumah sakit, dua rumah sakit belum bisa menangani persalinan caesar untuk pasien ODHA, hal tersebut dikarenakan Instalasi Bedah Sentral yang belum siap sehingga harus dirujuk. Menurut Merati, keterbatasan fasilitas untuk pelayanan kesehatan HIV dan AIDS seringkali dijadikan strategi untuk menutupi diskriminasi petugas kesehatan terhadap ODHA. Dengan alasan tersebut, petugas kesehatan seringkali menyarankan ODHA untuk mencari tempat layanan kesehatan lain supaya mereka terhindar dari tugasnya. Hal ini merupakan bentuk respon petugas kesehatan terhadap ketidaksiapannya menghadapi pasien HIV dan AIDS (Merati, 2005). Alasan salah satu dari dua rumah sakit tersebut belum bisa menangani persalinan pada pasien ODHA adalah karena pertimbangan non medis terkait dengan image pasien lain terhadap HIV dan AIDS, ditakutkan jika pasien lain tahu dampaknya akan mengubah image pasien terhadap pelayanan di tempat tersebut. Hal ini sejalan dengan hasil penelitian yang dilakukan oleh Merati dan kawan-kawan yang menunjukkan bentuk diskriminasi terhadap ODHA dalam pelayanan kesehatan diantaranya berupa penolakan pemberian layanan kesehatan pada ODHA dan perlakuan yang berbeda pada ODHA (Merati, 2005). Oleh karena itu, tenaga kesehatan sebagai pemberi layanan kesehatan perlu untuk lebih siap menghadapi pasien ODHA. Karena setiap orang berhak mendapatkan perawatan dan pengobatan yang sebaik-baiknya tanpa dibedaka (Murni, 2003).

\section{Pengetahuan}


Sebagian besar informan memiliki pengetahuan yang baik tentang HIV dan AIDS. Sebagian kecil informan telah mendapatkan pelatihan, sebagian kecil lainnya telah mendapatkan sosialisasi. Semua informan mengatakan pernah mendapatkan informasi tentang HIV dan AIDS, baik itu dari seminar, workshop, briefing, kuliah maupun dari buku dan literatur. Semua informan memiliki tingkat pengetahuan yang baik tentang kewaspadaan standar seperti pengertian, tujuan atau manfaat dari penerapan kewaspadaan standar. Namun satu informan mengakui bahwa sudah lupa dengan alur prosedur yang sesuai dengan SPO nya. Untuk itu kewaspadaan standar harus terus diingatkan yaitu dengan cara sosialisasi secara rutin, bisa dengan memanfaatkan conference atau forum-forum yang ada.

Hasil penelitian menunjukkan bahwa masih ditemukan adanya kesalahpahaman pengetahuan tentang HIV dan AIDS, yaitu sebagian kecil memiliki pemahaman yang salah, yaitu ada yang menganggap HIV dan AIDS tergolong penyakit autoimun, anggapan bahwa HIV dapat ditularkan melalui sentuhan dan pencegahan penularan HIV dilakukan dengan cara menjaga kesehatan daya tahan tubuh sehingga resiko dirinya tertular HIV dari pasien adalah rendah asalkan dapat menjaga kesehatan daya tubuhnya. Selain itu masih ada informan yang menganggap bahwa cara memperkecil resiko penularan HIV dari pasien HIV dan AIDS ke pasien lainnya adalah dengan melakukan isolasi. Dan ada yang mengatakan bahwa pencegahan penularan HIV dari ibu ke anak adalah ODHA tidak boleh hamil. Mereka yang memiliki pemahaman yang kurang ini memang belum mendapatkan pelatihan HIV dan AIDS meskipun mendapatkan informasi melalui seminar dan literatur. Hal ini menunjukkan bahwa pelatihan memberikan pemahaman yang lebih baik tentang HIV dan AIDS.

Selain itu mereka memiliki karakteristik umur $>40$ tahun. Hal ini menunjukkan bahwa dokter senior memiliki potensi pemahaman yang kurang karena materi HIV dan AIDS baru masuk ke dalam kurikulum ilmu kedokteran umum sekitar tahun 2005. Hal ini sesuai dengan informasi dari informan triangulasi bahwa belum semua dokter mendapatkan sosialisasi atau pelatihan tentang HIV dan AIDS, dan dokter-dokter angkatan senior banyak yang belum mendapatkan pemahaman tentang penyakit HIV dan AIDS. Namun pemberian informasi 
tentang HIV dan AIDS dapat dilakukan dengan memanfaatkan pertemuan-pertemuan rutin atau briefing-briefing secara rutin, sehingga informasi tentang HIV dan AIDS yang disampaikan bisa lebih mendalam untuk dipahami. Kurangnya pemahaman mengenai HIV dan AIDS ini dapat menyebabkan terjadinya diskriminasi terhadap ODHA.

Keterbatasan informasi dan pengetahuan tentang HIV dan AIDS menyebabkan rasa takut tertular virus HIV yang berlebihan pada petugas kesehatan dan seringkali menyebabkan diskriminasi dan tidak rasional terhadap ODHA (Robinson, 1998). Chase dan Aggleton et al, menyatakan bahwa rendahnya pengetahuan tentang penyakit AIDS, kesalahpahaman atau misinformasi $\begin{array}{lll}\text { tentang } & \text { bagaimana }\end{array}$ ditularkan/ditransmisikan dan rendahnya pengetahuan tentang pencegahan penyakit merupakan pemicu munculnya stigma dan diskriminasi terhadap ODHA (Chase \& Aggleton, 2001).

Pengetahuan tentang HIV dan AIDS sangat mempengaruhi bagaimana individu tersebut akan bersikap terhadap penderita HIV dan AIDS (Bradley, 2009). Pengetahuan pada umumnya merupakan domain yang sangat penting untuk terbentuknya perilaku dan mempengaruhi tindakan sehari-hari.
Sehingga, pemahaman pengetahuan yang baik tentang HIV dan AIDS dapat membentuk perilaku yang baik pula dalam pemberian pelayanan kesehatan kepada pasien HIV dan AIDS. Hasil penelitian ini sesuai dengan pendapat Notoatmodjo bahwa pengetahuan merupakan komponen pendukung perilaku yang utama (Notoatmodjo, 2007). Pendapat yang sama juga dikemukakan oleh teori Lawrence Green bahwa pengetahuan merupakan antesenden perilaku yang menyediakan alasan utama atau motivasi melakukan suatu tindakan (Glanz, 2002).

\section{Persepsi tingkat resiko penularan HIV}

Sebagian besar informan memiliki persepsi tingkat resiko penularan HIV di tempat layanan kesehatan yang rendah atau kecil jika kewaspadaan standar dan penggunaan APD diterapkan. Sebagian besar informan mengatakan bahwa jika harus menangani pasien ODHA mereka tidak merasa takut atau khawatir tertular dan hanya akan lebih berhati-hati saja. Sebagian kecil dari informan ini mengatakan lebih merasa takut tertular penyakit TBC dan hepatitis dari pasien ODHA tersebut.

Persepsi tingkat resiko penularan yang merupakan keyakinan adalah suatu bagian 
dari faktor predisposisi atau sering disebut sebagai faktor yang berkaitan dengan motivasi seseorang atau kelompok untuk melakukan segala tindakan. Teori Green juga mendasarkan diri pada model kepercayaan kesehatan atau health belief model yang mengatakan bahwa perilaku merupakan hasil dari sekumpulan kepercayaan kesehatan yang antara lain salah satunya adalah persepsi terhadap kerentanan (perceived susceptibility) (Graeff, 1996).

Kewaspadaan standar diciptakan untuk melindungi terhadap kecelakaan yang dapat terjadi. Kecelakaan yang paling umum adalah tertusuk jarum suntik, yaitu jarum suntik yang dipakai pada pasien menusuk kulit seorang petugas layanan kesehatan. Penelitian menunjukkan bahwa risiko penularan rata-rata dalam kasus pasien yang bersangkutan terinfeksi HIV adalah kurang lebih $0,3 \%$, dibandingkan dengan $3 \%$ untuk hepatitis C dan lebih dari 30\% untuk hepatitis B. Jika darah dari pasien yang terinfeksi mengenai selaput mukosa (misalnya masuk mata) petugas layanan kesehatan, risiko penularan HIV adalah kurang lebih 0,1\%. Walaupun belum ada data tentang kejadian serupa dengan darah yang tercemar hepatitis $\mathrm{B}$, risiko jelas jauh lebih tinggi (Yayasan Spiritia, 2013).
Namun demikian, ada anggapan yang masih salah, yaitu sebagian kecil informan menganggap tingkat resiko penularan HIV baginya kecil karena tidak perlu menyentuh pasien HIV dan asalkan dirinya menjaga daya tahan tubuhnya tetap baik. Satu informan menganggap resiko penularan HIV dari pasien ke pasien lainnya bisa dianggap besar jika pasien itu digabung dengan pasien lainnya dan semestinya pasien dengan HIV dipisahkan dengan pasien lainnya di ruang isolasi supaya tidak menularkan ke pasien lainnya. Selain itu, masih ada sebagian kecil dari informan yang merasakan kekhawatiran akan tertular HIV ketika menangani pasien ODHA. Sebagian kecil informan mengatakan bahwa resiko penularan HIV di tempat layanan kesehatan cukup besar yang menunjukkan masih ada sebagian kecil informan yang memiliki persepsi kerentanan (perceived susceptibility) yang tinggi karena menurut informan mereka memiliki resiko tertular HIV dan AIDS yang besar. Diskriminasi yang bertujuan untuk mencegah infeksi kadang-kadang tidak didasarkan pada risiko infeksi HIV yang sebenarnya tetapi pada pengetahuan ilmiah yang salah atau anggapan risiko potensial yang terlalu tinggi (overestimation potential risk) (Deacon, 2005). Informan yang memiliki persepsi 
bahwa tingkat resiko penularan HIV di tempat layanan kesehatan tinggi maupun yang memiliki persepsi kurang tepat ini belum mendapatkan pelatihan HIVAIDS meskipun mendapatkan informasi melalui seminar dan literatur. Hal ini menunjukkan bahwa pelatihan memberikan pemahaman yang lebih baik tentang HIV dan AIDS.

\section{Sikap}

Sebagian besar informan memiliki sikap positif yaitu jika menemui pasien dengan HIV dan AIDS ataupun yang masih dicurigai sebagai penderita HIV dan AIDS akan tetap melayani dan menangani (memeriksa dan mengobati) pasien sesuai dengan keluhan yang membuat pasien tersebut datang. Sebagian besar informan akan menawarkan untuk merujuk ke klinik VCT ketika menemui pasien yang memiliki indikasi gejala HIV dan AIDS.

Sebagian kecil informan akan melayani dan menangani dengan menekankan penerapan kewaspadaan universal yang sempurna. Satu informan mengatakan bahwa meskpiun ia mencurigai seorang pasien sebagai penderita HIV dan AIDS ia tidak merasa perlu untuk merujuk ke klinik VCT, namun akan tetap menangani pasien dengan lebih hati-hati dan waspada. Sebagian kecil dari informan mengatakan akan mengirimkan pasien yang dicurigai sebagai penderita HIV dan AIDS ke klinik VCT terlebih dahulu untuk mengetahui status HIVnya sebelum mau menangani pasien tersebut. Menurut informan triangulasi hal tersebut dilakukan sebagai langkah jika terjadi kecelakaan kerja untuk dapat melaksanakan prosedur profilaksis pasca pajanan. Karena untuk melakukan prosedur profilaksis pasca pajanan harus mengetahui status pasien tersebut benar-benar HIV positif. Mereka yang memiliki sikap lebih waspada dan lebih hati-hati jika harus menangani pasien ODHA ini belum mendapatkan pelatihan HIV dan AIDS meskipun mendapatkan informasi melalui seminar dan literatur. Hal ini menunjukkan bahwa pelatihan memberikan pemahaman yang lebih baik tentang HIV dan AIDS

Menurut Green, sikap adalah reaksi atau respon yang masih tertutup dari seseorang terhadap suatu stimulus atau objek. Menurut Azwar, sikap seseorang terhadap suatu objek adalah perasaan mendukung atau memihak (favorable) maupun perasaan tidak mendukung atau tidak memihak (unfavorable) pada objek tertentu. Sedangkan menurut Newcomb bahwa sikap merupakan kesiapan atau kesediaan untuk bertindak dan 
bukan merupakan pelaksanaan motif tertentu. Sejalan dengan teori L. Green maka sikap merupakan salah satu faktor pendahulu (antesenden) terjadinya suatu perilaku (Green, 2000).

\section{Stigma}

Semua informan sudah tidak memiliki stigma terhadap pasien ODHA, mereka mengatakan bahwa mereka sudah biasa saja dan tidak kaget dengan ODHA. Sebagian besar informan beranggapan bahwa pasien HIV tidak perlu ditakuti, tidak perlu dijauhi, dan harus ditolong dan diobati. Sebagian besar informan menganggap bahwa penyakit HIV dan AIDS sebagai penyakit infeksi menular yang tidak bisa disembuhkan tetapi ada obat untuk mempertahankan hidup secara normal.

Sebagian kecil informan masih menganggap bahwa penyakit HIV dan AIDS adalah penyakit yang mematikan, penyakit yang membahayakan, dan menyeramkan karena belum ada obat yang bisa menyembuhkan. Masih ada satu dokter yaitu dokter umum yang merasa simpati hanya pada pasien HIV yang dia anggap sebagai korban dan merasa gemas pada ODHA yang merupakan pelaku.
Menurut hasil penelitian, sebagian besar informan menganggap bahwa penyakit HIV dan AIDS sebagai penyakit infeksi menular yang tidak bisa disembuhkan tetapi ada obat untuk mempertahankan hidup secara normal. Namun, sebagian kecil informan masih menganggap bahwa penyakit HIV dan AIDS adalah penyakit yang mematikan, penyakit yang membahayakan, dan menyeramkan karena belum ada obat yang bisa menyembuhkan.

Persepsi terhadap pengidap HIV atau penderita AIDS akan sangat mempengaruhi bagaimana orang tersebut akan bersikap dan berperilaku terhadap ODHA (Cock, 2002). Herek et al, menyatakan bahwa stigma dan diskriminasi terhadap ODHA muncul berkaitan dengan ketidaktahuan tentang mekanisme penularan HIV, perkiraan resiko tertular yang berlebihan melalui kontak biasa dan sikap negatif terhadap kelompok sosial yang tidak proporsional yang dipengaruhi oleh epidemik HIV dan AIDS ini (Herek, 2002).

Hasil penelitian menunjukkan meskipun pada awalnya sebagian kecil informan memiliki stigma yaitu berpikiran jelek dan merendahkan terhadap pasien HIV dan AIDS (karena konotasi penyakit HIV dan AIDS yang disebabkan oleh perilaku yang dianggap 
tidak benar di masyarakat) namun setelah menemui sendiri bahwa HIV dan AIDS bisa terjadi pada siapa saja termasuk pada orang yang tidak melakukan perilaku beresiko, cara pandang informan telah berubah. Hal itu menunjukkan bahwa pengalaman menangani ODHA mempengaruhi pandangan atau stigma pada pasien ODHA.

Dalam penelitian tentang sikap petugas kesehatan terhadap pasien ODHA di Australia, McCann menemukan adanya hubungan yang signifikan antara kontak sosial dan pengalaman kerja dengan ODHA dengan sikap petugas kesehatan terhadap ODHA (McCan, 1997). Hal yang sama juga ditemukan R. Alexander dan J. Fitzpatrick dalam penelitiannya dimana petugas kesehatan yang pernah menolong $>15$ orang pasien ODHA memiliki sikap positif dibandingkan mereka yang berpengalaman menolong 12-14 orang pasien ODHA (Alexander, 1991).

\section{Dukungan Institusi}

Ada dukungan yang baik dari pihak rumah sakit dalam hal ketersediaan alat pelindung diri, yaitu sarana untuk penerapan kewaspadaan universal seperti handscoon, masker, pelindung mata, celemek, dan penutup kepala selalu tersedia dan mencukupi kebutuhan untuk penanganan pasien. Masing-masing rumah sakit telah memiliki kebijakan dalam bentuk standar operasional prosedur mengenai kewaspadaan standar meliputi standar operasional prosedur cuci tangan, dan standar operasional prosedur pemakaian alat pelindung diri serta telah mensosialisasikannya. Menurut informan triangulasi, sosialisasi tersebut merupakan program dari tim pengendalian infeksi atau INOS dan sosialisasi juga dapat dilakukan pada saat in house training.

Masing-masing rumah sakit telah memiliki kebijakan untuk pelayanan HIV dan AIDS dan telah dituangkan dalam bentuk Standar Prosedur Operasional (SPO). SPO yang ada diantaranya adalah SPO tentang Penanganan Pasien HIV dan AIDS dan Pemberian ARV, SPO untuk konseling pra dan post test, SPO tentang Penatalaksanaan Paparan Cairan Tubuh Pasien Terinfeksi HIV pada Pegawai Rumah Sakit, SPO tentang Pedoman Tatalaksana Pengobatan HIV dan AIDS pada Anak, dan ada juga Prosedur Tetap (Protap) tentang Pemulasaran Jenazah HIV dan AIDS.

Semua informan mengatakan ada sosialisasi tentang penerapan kewaspadaan standar. Menurut informan triangulasi pada masing-masing rumah sakit telah 
mengadakan in house training untuk petugas kesehatan yang mana didalamnya ada materi tentang HIV dan AIDS dan universal precautions. Menurut informan triangulasi, masih banyak petugas kesehatan yang belum mendapatkan kesempatan mengikuti in house training. Salah satu rumah sakit hanya mengadakan pelatihan ini untuk perawat. Sedangkan di rumah sakit lainnya juga mengundang dokter, namun hanya dokter yang berkaitan erat dengan pelayanan HIV, sedangkan rumah sakit yang lain hanya mengundang dokter yang merupakan karyawan tetap rumah sakit tersebut.

Menurut informan triangulasi di dua rumah sakit menyatakan bahwa tidak ada teguran ketika tenaga kesehatan tidak menerapkan kewaspadaan standar, yang ada hanya berupa peringatan bisa secara langsung oleh kepala ruang, atau sekedar peringatan dari sesama rekan kerja. Sedangkan satu rumah sakit mengatakan bahwa biasanya akan ada teguran dari atasan ketika diketahui tidak menerapkan kewaspadaan standar.

Faktor dukungan institusi pelayanan kesehatan mempengaruhi praktik pelayanan kesehatan terhadap ODHA, antara lain halhal yang terkait penetapan kebijakan, SOP (Standart Operational Procedure), penyediaan sarana, fasilitas, bahan dan alat- alat perlindungan diri dalam penanganan pasien HIV dan AIDS (Li, 2007). Menurut Lawrence Green, kebijakan adalah seperangkat peraturan yang digunakan sebagai petunjuk untuk melaksanakan kegiatan (Green, 2000).

\section{Sikap dan Perilaku Rekan Kerja}

Rata-rata informan mengatakan bahwa rekan kerja atau tenaga kesehatan yang lain bersikap biasa saja dan mau menangani pasien ODHA. Sebagian kecil dari informan mengatakan bahwa tenaga kesehatan yang lain masih ada yang takut atau tidak berani untuk menangani pasien dengan HIV dan AIDS. Sebagian kecil lainnya dari informan mengatakan bahwa pada tenaga kesehatan yang lain masih ada stigma terhadap penyakit HIV dan AIDS. Ada informan yang mengatakan bahwa terkadang sikap dari tenaga kesehatan lain berlebihan dalam penggunaan APD sebagai perlindungan dirinya. Menurut informan, masih ada rekan dokter yang takut dan berlebihan seperti selalu menggunakan masker dan sarung tangan saat menangani ODHA. Hal ini sejalan dengan penelitian Harapan, et al yang menyatakan bahwa masih ada tenaga kesehatan yang bersikap mendiskriminasi pasien ODHA yaitu dengan menggunakan 
sarung tangan selama semua interaksi (Harapan, 2013).

Hasil penelitian menunjukkan bahwa masih ada rasa takut dan stigma pada tenaga kesehatan di rumah sakit rujukan HIV dan AIDS. Menurut Lawrence Green, sikap dan perilaku rekan kerja merupakan dukungan atau dorongan yang berasal dari lingkungan sosial dan orang lain yang berpengaruh akan memberikan stimulus yang mempunyai efek berkelanjutan terhadap suatu perilaku (Green, 2000).

\section{SIMPULAN}

Sebagian besar informan berpraktik baik dalam pemberian pelayanan kesehatan pada pasien HIV dan AIDS. Mereka tidak melakukan pembedaan perlakuan atau tidak mendiskriminasi saat memberikan pelayanan kesehatan kepada pasien HIV dan AIDS seperti tidak ada penolakan pelayanan, tidak ada perbedaan dalam penerapan kewaspadaan standar, tidak memberikan tanda khusus atau label di depan catatan medis, tidak ada pemisahan ruangan, dan tidak ada penundaan pelayanan.

Namun, masih ada sebagian kecil informan yang berpraktik kurang baik dalam pemberian pelayanan kesehatan pada pasien HIV dan AIDS. Mereka memberikan perlakuan yang berbeda atau cenderung diskriminatif ketika memberikan pelayanan kesehatan kepada pasien HIV dan AIDS. Sebagian kecil informan memiliki pengetahuan yang kurang tentang HIV dan AIDS, memiliki persepsi bahwa tingkat resiko penularan HIV di tempat layanan kesehatan tergolong tinggi sehingga sebagian kecil informan masih merasakan kekhawatiran akan tertular HIV ketika menangani pasien ODHA. Sikap sebagian kecil informan akan melayani dan menangani dengan menekankan penerapan kewaspadaan universal yang sempurna. Sebagian kecil informan mengatakan bahwa sikap dan perilaku rekan kerja atau tenaga kesehatan yang lain kurang baik yaitu masih ada yang takut atau tidak berani untuk menangani pasien dengan HIV dan AIDS dan masih ada stigma terhadap penyakit HIV dan AIDS.

\section{ACKNOWLEDGEMENT}

Dalam hal ini penulis mengucapkan terima kasih kepada Menteri Pendidikan Nasional yang telah memberikan dukungan pembiayaan melalui Program Beasiswa Unggulan jalur Fast Track berdasarkan DIPA Sekretariat Jenderal Departemen Pendidikan Nasional Tahun Anggaran 2012 sampai dengan Tahun 2014. 


\section{KEPUSTAKAAN}

Alexander $\mathrm{R}$ and Fitzpatrick J. Variable Influencing Nurses' Attitudes Towards AIDS and AIDS Patients. AIDS Care. 1991;5(6):315-20.

Andrewin A, Chien LY. Stigmatization of Patients with HIV/AIDS among Doctors and Nurses in Belize. AIDS Patient Care and STDs. 2008;22(11):897-906.

Bradley J, et al. Changes in HIV Knowledge, and Socio-Cultural and Sexual Attitudes in South India from 20032009. BMC Public Health. 2009;11(Suppl.6):S12.

Chase E and Aggleton P. Stigma, HIV/AIDS and Prevention of Mother To Child Transmission : A Pilot Study in Zambia, India, Ukraine, and Burkina Faso. UNICEF. London. 2001.

Cock KMD, Mbori-Ngacha D and Marum E. Shadow on the continent : Public Health and HIV/AIDS in Africa in the 21 st century. The Lancet. 2002;360(9326):67-72.

Deacon H, Stephney I, and Prosalendis S. Understanding HIV/AIDS Stigma: A Theoritical and Methodological Analysis. HSRC Press. Cape TownSouth Africa. 2005.

Dinas Kesehatan Kota Semarang. Laporan Situasi HIV AIDS di Kota Semarang 2013. Dinas Kesehatan Kota. Semarang. 2014.

Dinas Kesehatan Kota Semarang. Profil Kesehatan Kota Semarang 2013. Dinas Kesehatan Kota. Semarang. 2014.

Graeff JA, Elder JP, and Booth EM. Komunikasi untuk Kesehatan dan Perubahan Perilaku. Gadjah Mada University Press. Yogyakarta. 1996.

Glanz K, Rimer BK, and Lewis FM. Health Behavior and Health Education: 
Theory, Research, and Practice. Jossey-Bass, San Fransisco, 2002.

Green LW, Kreuter, and Marshal W. Health Promotion Planning An Educational and Environmental Approach 2nd Edition. Mayfield Publishing Company. Mountain View-TorontoLondon. 2000.

Harapan H, Feramuhawan S, Kurniawan H, Anwar S, Andalas M, and Hossain MB. HIV-related Stigma and Discrimination: A Study of Health Care Workers in Banda Aceh, Indonesia. Med $J$ Indones. 2013;22(1):22-29.

Harapan H, et al. Discriminatory Attitudes Toward People Living With HIV Among Health Care Workers in Aceh, Indonesia: A Vista From A Very Low HIV Caseload Region. Clinical Epidemiology and Global Health. 2013;08(001):1-8.

Herek GM, Capitanio JP and Widaman KF. HIV-Related Stigma and Knowledge in the United States: Prevalence and Trends, 1991-1999. American Journal of Public Health. 2002;92(3). International Labour Organization \& World Health Organization. Pedoman Bersama ILO/WHO Tentang Pelayanan Kesehatan dan HIV/AIDS. Direktorat Pengawasan Kesehatan Kerja. Jakarta. 2005.

Kementerian Kesehatan RI. Statistik Kasus HIV/AIDS di Indonesia: dilapor sampai dengan Juni 2013. Diakses melalui:URL:

spiritia.or.id/Stats/StatCurr.pdf

diakses pada Maret, 2014.

Kementerian Kesehatan Republik Indonesia. 2012. Keputusan Menteri Kesehatan Republik Indonesia Nomor 451/ Menkes/ SK/ XII/ 2012 tentang Rumah Sakit Rujukan Bagi Orang Dengan HIV dan AIDS.
Kementerian Kesehatan RI. Laporan Situasi Perkembangan HIV \& AIDS di Indonesia Tahun 2013. Kemenkes RI. Jakarta. 2013. Diakses melalui:URL:http://www.aidsindonesi a.or.id/ck_uploads/files/Laporan\%20 HIV\%20AIDS\%20TW\%202\%20201 $3 \% 20$ FINAL.pdf diakses pada Maret, 2014.

Kementerian Kesehatan RI. Pedoman Penghapusan Sigma dan Diskriminasi Bagi Pengelola Program, Petugas Layanan Kesehatan dan Kader. Kemenkes RI. Jakarta. 2012.

Kinsler JJ, Wong MD, Sayles JN, Davis C, and Cunningham WE. The Effect of Perceived Stigma from a Health Care Provider on Access to Care Among a Low-Income HIV-Positive Population. Journal AIDS Patient Care and STDs. 2007;21(8).

Komisi Penanggulangan AIDS Nasional. ODHA dan Akses Pelayanan Kesehatan Dasar: Penelitian Partisipatif. KPAN. Jakarta. 2006. Diakses melalui:URL: http://www.spiritia.or.id/Dok/odhaaks es.pdf diakses pada Oktober, 2013.

Li L, Wu Z, Wu S, Zhaoc Y, Jia M and Yan Z. HIV-Related Stigma in Health Care Settings: A Survey of Service Providers in China. AIDS Patient Care STDS. 2007;21(10):753-62.

Mahendra V, et al. Understanding and Measuring AIDS-Related Stigma in Health Care Settings: A Developing Country Perspective. Journal of Social Aspects of HIV/AIDS. 2007;4(2):616-25.

Mardiati R, Handayani S. Ringkasan Eksekutif: Penelitian Peran Dukungan Sebaya Terhadap Peningkatan Mutu Hidup ODHA di Indonesia Tahun 2011. Yayasan 
Spiritia. Jakarta. 2011. Diakses melalui:URL:http://spiritia.or.id/Dok/ Ringkasan_Penelitian_Peran_Dukung an_Sebaya.pdf diakses pada Desember, 2013.

McCann TV. Willingness to Provide Care and Treatment for Patient with HIV/AIDS. Journal of Advanced Nursing. 1997;25(5):1033-9.

Merati TP and Supriyadi FY. The Disjunction Between Policy and Practice: HIV Discrimination in Health Care and Employment in Indonesia. AIDS Care. 2005;17 (Suppl.2):175-9.

Murni S, Green CW, Okta S, and Setyowati H. Pasien Berdaya. Yayasan Spiritia. Yogyakarta. 2003.

Notoatmodjo S. Pengantar Pendidikan Kesehatan dan Ilmu Perilaku. Rineka Cipta. Jakarta. 2007.

Nurhayati E. Stigma dan Diskriminasi Terhadap ODHA di Kota Bandung Tahun 2012. Pustaka Universitas Padjadjaran. Bandung. 2013.

Paryati T, Raksanagara AS, Afriandi I. Faktor-faktor yang Mempengaruhi Stigma dan Diskriminasi kepada ODHA(Orang dengan HIV/AIDS) oleh Petugas Kesehatan : Kajian Literatur. Pustaka Universitas Padjadjaran. Bandung. 2013.

Purwaningtyas A, Subronto YW, and Hasanbasri M. Pelayanan HIV/AIDS di RSUP Dr. Sardjito Yogyakarta. Universitas Gadjah Mada Press. Yogyakarta. 2007.

Robinson N. People with HIV/AIDS: Who Cares?. Journal of Advanced Nursing. 1998;28(4):771-8.

Rostini. Faktor-Faktor yang Berhubungan dengan Sikap Petugas Puskesmas Terhadap Orang Dengan HIVAIDS (ODHA) dalam Pelayanan Kesehatan HIV-AIDS di Kota Bandung Tahun
2010. Tesis (Universitas Indonesia). Depok. 2010.

Webber GC. Chinese Health Care Providers' Attitude About HIV: A Review. AIDS Care. 2007;19(5):685-91.

Yayasan Spiritia. Lembaran Informasi tentang HIV/AIDS untuk Orang Yang Hidup Dengan HIV/AIDS (ODHA) Kewaspadaan Standar. Yayasan Spiritia. Jakarta. 2013.

Yayasan Spiritia. Dokumentasi tentang Masalah Diskriminasi terhadap Orang dengan HIV/AIDS di Indonesia: Tahap Kedua. Yayasan Spiritia. Jakarta. 2005. Diakses melalui:URL:

http://www.spiritia.or.id/Dok/HR-

Dok2.pdf diakses pada Oktober, 2013. 